\title{
TAXES, CONSCIENCE, AND THE CONSTITUTION
}

\author{
Steven D. Smith*
}

\section{TAX EXPENDITURES AND THE CLAIMS OF CONSCIENCE}

Al Agnostic and Betty Basic are neighbors-and citizens. They are also taxpayers. As humans, they do not especially relish paying taxes, but as citizens they understand that taxes are a civic necessity and obligation. Like most citizens, $\mathrm{Al}$ and Betty approve of some of the uses to which their tax dollars are devoted, and they disapprove of other uses. Sometimes they disapprove on grounds of policy: they simply do not think that particular expenditures are a good use of public funds. Sometimes their disapproval runs deeper: they might express this deeper opposition by saying that they are opposed "in conscience" to particular expenditures of public money.

Naturally, the specific expenditures that provoke such scruples differ as between $\mathrm{Al}$ and Betty. As an agnostic, $\mathrm{Al}$ opposes public expenditures that he sees as supporting or advancing religion. So he objects to the inclusion of religious institutions in publicly-supported programs established to provide social services like job training or drug rehabilitation (the so-called "faithbased initiatives"), and he also opposes the subsidization of religious schools (as in so-called voucher programs). By contrast, Betty is supportive of these types of expenditures. But as an evangelical Christian she is conscientiously opposed to programs that she sees as supporting or condoning premarital sex. And she is especially pained to think that her tax dollars are being used in the public schools to support the teaching of evolution and other ideas that she believes to be false, corrosive of civic virtue, and

* Warren Distinguished Professor of Law, University of San Diego. I thank Larry Alexander, Ed Eberle, Tony Ellis, and participants in a workshop at Chicago-Kent for helpful comments on an earlier draft. 
subversive of what she regards as the saving faith that she hopes to instill in her children and neighbors.'

So, do either Al's or Betty's objections have any sort of constitutional status? More specifically, can $\mathrm{Al}$ or Betty plausibly claim a constitutional right to freedom of conscience that is violated when he or she is forced to pay taxes that will be used in part for these objectionable purposes?

It is not hard to imagine a possible (though perhaps not very viable) argument suggesting that both $\mathrm{Al}$ and Betty's objections ought to have constitutional status. $\mathrm{Al}$ and Betty might join in urging the proposition that in a community that respects "the sanctity of conscience," citizens should not be forced to subsidize governmental activities to which they are conscientiously opposed. The First Amendment, with its assorted clauses protecting the free exercise of religion and the freedom of speech, is sometimes viewed as a haven for conscience. ${ }^{2}$ So Al and Betty might try to anchor their appeals to conscience in that amendment.

In the abstract, it should not be hard to appreciate the appeal - and the logic - of this argument. Nor should it be hard to appreciate the overwhelming practical objections that the argument will provoke. After all, many citizens and taxpayers will say, sincerely, that they are opposed in conscience to any number of things that (with the support of their tax dollars) government does. Some citizens are conscientiously opposed to particular (or ail) military activities, others to particular government funded programs in the arts or in science, others to an array of "liberal" or "conservative" social programs. We can appreciate the problem if we let our imaginations run just a little and suppose that Al's and Betty's argument were actually accepted by the courts: millions of citizens who have been thus encouraged to develop bloated consciences might thereby excuse themselves from all manner of taxes.

That nightmare may easily lead us to the opposite conclusion: neither $\mathrm{Al}$ nor Betty should be deemed to have a valid objection. More generally, objections of conscience cannot be per-

1. Citizens with this perspective are recognized in both scholarly and judicial legal litcrature. See, e.g., Nomi Maya Stolzenberg, "He Drew a Circle that Shut Me Out": Assimilation, Indocirination, and the Paradox of a Liberal Education, 106 HARV. L. REV. 581 (1993); Mozert v. Hawkins County Bd. of Educ., 827 F.2d 1058 (6th Cir. 1987).

2. See, e.g., J. John Paul Stevens, The Freedom of Speech, 102 Yale L.J. 1293, 1297 (1993) (describing "'the individual freedom of conscience protected by the First Amendment"') (quoting Wallace v. Jaffree, 472 U.S. 38 (1985)). 
mitted to excuse citizens from their basic civic obligation to pay taxes, even if these citizens have sincere moral objections (as many surely will) to some of the things government does with their money. ${ }^{3}$

So there is an intelligible argument for accepting both Al's and Betty's claims of conscience, and there is a realistically more acceptable argument for rejecting both arguments. We can also imagine an argument that might support Betty's claim of conscience but not Al's. After all, our Constitution does not explicitly recognize any "freedom of conscience"-such language was proposed when the First Amendment was drafted, only to be rejected ${ }^{4}$-but the Constitution does have a provision recognizing the right to "free exercise of religion." We can stipulate that Al's and Betty's objections are equally sincere and equally conscientious, but we have also supposed that Betty's objection is grounded in religious belief; Al's is not. So Betty's claims may seem more at home in the Constitution as it is written. ${ }^{5}$

Can we imagine an argument for the opposite result - for recognizing Al's claim of conscience but not Betty's? At least on first reflection, this alternative seems untenable. As noted, $\mathrm{Al}$ cannot as plausibly invoke the protection of the right to "free exercise of religion." Nor can he as easily ground his objection in the rationales that historically were offered for protecting rights of free exercise or of conscience. Claims of conscience were typically asserted in reaction to attempts to coerce people in matters of religion, and according to the classic defenses developed by luminaries like Roger Williams and John Locke and James Madison, ${ }^{6}$ such coercion was wrong because forced worship or religiosity is unacceptable to God-it "stincks in God's Nostrills," in Williams's pungent phrase. ' It is doubtful whether Betty can successfully assert this rationale in this context, ${ }^{8}$ but

3. This rejection would seem to apply as well, perhaps a fortiori, to citizens who have conscientious objections not to the way their tax dollars are spent, but to the pay. ment of taxes itself. See United States v. Lee, 455 U.S. 252 (1982)

4. See Michael W. McConnell, The Origins and Historical Understanding of Free Exercise of Religion, 103 HARV. L. REV. 1409, 1481-84 (1990).

5. For an assessment of the question whether the free exercise clause protects nonreligious manifestations of conscience, see Steven D. Smith, What Does Religion Have to Do with Freedom of Conscience?, 76 U. COLO. L. REV. 911 (2005).

6. For an overview, see ReX AHdar \& IAN LEIGH, Religious FreEdom IN THE LIBERAL STATE 22-36 (2005)

7. See Edward J. Eberle, Roger Williams on Liberty of Conscience, 10 ROGER WILLIAMS U. L. REV. 289, 297 (2005). For a more recent version of this rationale, see JOHN H. GARVEY, WHAT ARE FREEDOMS FOR? 49-57 (1996).

8. Betty can claim that payment of taxes for this purpose violates God's will, but 
surely $\mathrm{Al}$ cannot cogently invoke it: after all, $\mathrm{Al}$ does not even believe that God exists.

So perhaps we should be surprised to learn that a common view today, advocated by jurists like Justice David Souter ${ }^{9}$ and by scholars like Noah Feldman, ${ }^{10}$ would recognize Al's claim of conscience while politely declining to notice Betty's. Moreover, people who take this view often try to support it by quoting language from venerable sources such as James Madison and Thomas Jefferson. ${ }^{11}$ It is a curious position but also a longstanding one-and one that is arguably at the core of the distinctively American commitment to the nonestablishment of religion. Let us investigate that position more closely.

\section{FROM CONSCIENCE (THROUGH TAXES) TO NONESTABLISHMENT?}

In Zelman v. Simmons-Harris, ${ }^{12}$ the Supreme Court upheld a Cleveland voucher program that included religious schools among the institutions eligible to receive public funding. Dissenting, Justice Souter argued that the program violated the consciences of taxpayers, and he quoted in support of this claim James Madison's famous statement that conscience is offended by any law that would "force a citizen to contribute three pence ... of his property for the support of any ... establishment." 13

The basic argument had been made countless times before, of course. And in a sense it seems almost truistic: if the Constitution forbids government to establish religion (a proposition that by now is very well settled ${ }^{14}$ ), and if the inclusion of religious schools in a more general program of educational support is an establishment of religion (a proposition that remains hotly contested), then it would seem to follow that the Cleveland voucher program violated the Constitution-even if the amount of funding directed to religious schools was relatively small (as it argua-

she cannot cogently make the classical argument about the inefficacy of forced worship, since the government is not attempting to induce her to worship.

9. See infra note 13 and accompanying text.

10. See NoAh FELdMan, Divided By God 33-43, 246-47 (2005).

11. See id. at 33-43.

12. 536 U.S. $639(2002)$.

13. Id. at 711 (Souter, J, dissenting).

14. For at least the first century or so of the Republic, the prevailing view had been that the First Amendment prohibited the national government but not the states from establishing religion. The turning point came with Everson v. Board of Education, 330 U.S. 1 (1947). 
bly was not). "No aid" separationists have been making this argument almost from time immemorial, ${ }^{15}$ or so it seems, and in the last century their position often prevailed (though perhaps less often toward the end of the century than closer to the middle $)^{16}$.

This argument can be made, however, and often is made, without any invocation of freedom of conscience. The "no aid" separationist can simply point out that the First Amendment contains a clause forbidding establishments of religion and then argue that a voucher program including religious schools transgresses this prohibition. There seems to be no need to bring individual conscience into the argument at all. Conversely, "freedom of conscience" would seem to resonate more naturally with the free exercise clause than with the nonestablishment prohibition.

Why then did Justice Souter emphasize that the allocation of public money to religious education violated the consciences of taxpayers? Though we can only guess at Souter's particular motivations, we can also imagine reasons why "no aid" separationists might want to assert a link between freedom of conscience, taxes, and nonestablishment. Let us briefly notice four such reasons.

First, a commitment to nonestablishment might be made stronger, and more rhetorically powerful, if tied to a commitment to freedom of conscience. The case for respecting conscience is arguably more compelling than the case for constitutionally mandated nonestablishment. Conscience is an intimate personal concern - one that looks and sounds like the subject of a "right," even a "natural right" - while nonestablishment is more institutional and structural and abstract. Long before arguments for religious disestablishment went mainstream, major theorists like Locke along with scores of by-now-forgotten polemicists were pressing arguments for freedom of conscience. ${ }^{7}$ Even today, international human rights law embraces freedom of conscience but does not mandate nonestablishment. ${ }^{18}$ And nations

15. See generally Philip Hamburger, Separation of Church and STATE (2002)

16. For an overview of these developments, see JOHN WITTE JR., RELIGION AND THE AMERICAN CONSTITUTIONAL EXPERIMENT 149-84 (2000).

17. For a scholarly overview of the historical developments, see ANDREW MURPHY, CONSCIENCE AND COMMUNITY: REVISITING TOLERATION AND RELIGIOUS DISSENT IN EARLY MODERN ENGLAND AND AMERICA (2001).

18. See Michael J. Pcrry, What Do the Free Exercise and Nonestablishment Norms Forbid?: Reflections on the Constitutional Law of Religious Freedom, 1 UNIV. OF ST. 
we regard as civilized and progressive and supportive of religious freedom-England, for example-maintain established churches.

In short, standing alone, the constitutional commitment to nonestablishment may seem vulnerable. Perhaps that commitment would be rendered more secure if it could be tied successfully into the more unassailable right to freedom of conscience.

Second, and more technically, linking nonestablishment to conscience may solidify the anomalous doctrine whereby taxpayers are treated as having legal standing to challenge violations of the nonestablishment provision. Typically, the fact that a person pays taxes is not enough to permit him to bring a lawsuit challenging a constitutional infraction, ${ }^{19}$ even one involving the expenditure of public funds; the successful plaintiff needs to be able to assert a more concrete and particularized injury. ${ }^{20}$ Even if the consequence of this requirement is that no one has standing to challenge a constitutional violation, the courts have sometimes insisted on a showing of such personalized harm. ${ }^{21}$ In the area of nonestablishment, however, the courts have departed from this position, routinely allowing litigants to claim "taxpayer standing." 22 Erwin Chemerinsky reports that "the only situation in which taxpayer standing appears permissible is if the plaintiff challenges a government expenditure as violating the establishment clause."

But why? The Supreme Court's own explanation of the exception borders on gibberish. ${ }^{24}$ But if taxpayers can plausibly claim that the use of their money to advance religion violates their consciences, then arguably the requisite personalized harm would be present. After all, a violation of conscience seems about as personal a harm as one could hope for.

ThOMAs L.J. 549, 564 (2003) (observing that "the international law of human rights does not include anything like the American nonestablishment norm").

19. See Frothingham v. Mellon, 262 U.S. 447 (1923).

20. See ERWIN CHEMERINSKY, FEDERAL JURISDICTION 52 (1989).

21. United States v. Richardson, 418 U.S. 166 (1974); Schlesinger v. Reservists Commiltee to Stop the War, 418 U.S. 208 (1974)

22. For a recent instance with a scholarly opinion by Judge Richard Posner and a thoughtlul dissent by Judge Kenneth Ripple, see Freedom from Religion Foundation v. Chao, 74 U.S.L.W. 1446 ( 7 th Cir. 2006) (upholding taxpayer standing in suit challenging Bush Administration program promoting "faith-based initiatives")

23. CHEMERINSKY, supra note 20 , at 82

24. Flast v. Cohen, 392 U.S. 83 (1968). See especially the dissenting opinion by Justice Harlan 
Third, if state monetary support for religion violates the consciences of taxpayers, a long-standing embarrassment in the constitutional doctrine of "incorporation" might be allayed. As all law students know, the Bill of Rights did not originally apply to the states, nor did the Supreme Court ever hold that the Fourteenth Amendment incorporated the Bill of Rights per se against the states (Justice Black notwithstanding). Instead, the Court ruled that the Fourteenth Amendment's due process clause included certain substantive rights that were "implicit in the concept of ordered liberty," 25 or "deeply rooted in this Nation's history and tradition." 26 And the Court treated various provisions in the Bill of Rights as authoritative expressions of some of these rights. Though often critical of the path taken by the Court, scholars have argued for a similar overall outcome by contending that rights contained in the Bill of Rights should have been treated as among the "privileges and immunities" referred to in the Fourteenth Amendment. ${ }^{27}$

Under these "rights" rationales, it is easy enough to say that the Fourteenth Amendment incorporated the free exercise clause - or perhaps some more general right to freedom of conscience emanating from the free exercise and free speech clauses. ${ }^{28}$ But it is conceptually awkward to say that a merely structural limitation on the national government was somehow incorporated against the states. Thus, scholars and jurists have sometimes argued that the establishment clause (at least in its original meaning) could not have been incorporated against the states: the claim simply defies logic. ${ }^{29}$ But if the payment of taxes to be used for religious purposes violates the taxpayers' rights of conscience, so that nonestablishment is a corollary of freedom of conscience, then this objection is readily overcome. That is because, once again, a right of conscience has a strong claim to being "deeply rooted in this Nation's history and tradition."

Finally, for those who believe that "original meaning" should count heavily or decisively in constitutional interpretation, linking "no aid" nonestablishment to freedom of conscience might be helpful in parrying a threatening interpretation of the original meaning of the religion clauses. In recent years,

25. Palko v. Connecticut, 302 U.S. 319, 325 (1937).

26. Moore v. City of East Cleveland, 431 U.S. 494, 503 (1977).

27. See, e.g., AKHIL REed AMAR, The Bill of Rights 181-87 (1998).

28. See Cantwell v. Connecticut, 310 U.S. 296 (1940).

29. See, e.g., AMAR, supra note 27, at 41. See also Note, Rethinking the Incorpora tion of the Establishment Clause: A Federalist View, 105 HARV. L. REV. 1700 (1992). 
some scholars (joined recently by Justice Clarence Thomas ${ }^{30}$ ) have argued that the establishment clause was not originally intended to constitutionalize any particular substantive principle or right of religious freedom, but was merely intended to confirm the jurisdictional arrangement whereby religion was a matter for the states, not the national government. ${ }^{3{ }^{\circ}}$ One argument in support of this jurisdictional interpretation grows out of the fact of widespread disagreement during the founding period about the proper relation between government and religion: some citizens and states (Jefferson, and Virginia, for example) had concluded that government should not support religion, but other citizens and states (such as the Congregationalists in Massachusetts and Connecticut) believed that government support for religion was proper and necessary. Given this disagreement, supporters of the jurisdictional interpretation ask, how could Americans have converged to approve any substantive principle of religious freedom or nonestablishment? Instead, the Framers steered around substantive differences by simply agreeing that jurisdiction over such matters would remain where it had always been - with the states. ${ }^{32}$

Opponents of this jurisdictional interpretation typically argue that despite their conspicuous differences, Americans of the period agreed on certain general principles in matters of religion. Specifically, they shared a commitment to freedom of conscience. ${ }^{33}$ But even if it is persuasive, the argument asserting a consensus on conscience would seem most pertinent to the free

30. See, e.g., Cutter v. Wilkinson, 544 U.S. 709, 726 (2005) (Thomas, J., concurring).

31. I have argued at length for this interpretation elsewhere. Steven D. Smith, The Jurisdictional Establishment Clause: $A$ Reappraisal, 81 NOTRE DAME L. REV. 1843 (2006); STEVEN D. SMITH, Foreordained FaILure: THE Quest For A CONSTITUTIONAL PRINCIPLE OF REligious FreEdom (1995).

32. Douglas Laycock, though a critic of this interpretation, explains that "[1]here was not yet a consensus for disestablishment, which suggests that the Founders might not have been able to agree on a substantive understanding of the Establishment Clause. But they did not have to agree on disestablishment; they had to agree only on what powers they were denying to the lederal government." Douglas Laycock, Comment, Theology Scholarships, The Pledge of Allegiance, and Religious Liberty: Avoiding the Extremes But Missing the Liberty, 118 HARV. L. REV. 155, $241-42$ (2004). See also Daniel O. Conkle, Toward a General Theory of the Establishment Clause, 82 NW. U. L. REV. 1113, 1133-35 (1988).

33. See, e.g., FeldMan, supra note 10, at 27-33. For Feldman's more developed argument, see Noah Feldman, The Intellectual Origins of the Establishment Clause, 77 NYU L. REV. 346 (2002). See also Steven K. Green, Federalism and the Establishment Clause: A Reassessment, 38 CREIGHTON L. REV. 761, 775 (2005) ("Moreover, Americans throughout the fourteen nascent states agreed that freedom of religious conscience was an essential right."). 
exercise clause. What does that argument have to do with the establishment clause?

While exploring various difficulties with the argument, Noah Feldman suggests that "no aid" nonestablishment can be derived from the shared commitment to freedom of conscience. ${ }^{34}$ Why? Because forcing taxpayers to support religions contrary to their beliefs is a violation of their freedom of conscience. So if Americans of the period agreed in supporting freedom of conscience, they effectively agreed on a principle of "no financial aid" to religion as well.

\section{CONNECTIONS HISTORICAL AND LOGICAL-OR NOT}

In sum, the contention linking conscience to nonestablishment via taxes may be important to the separationist position (and, arguably, to the distinctive American commitment to nonestablishment itself) in a variety of ways. This contention can be advanced or understood in two quite different senses, or in terms of what we can call "the historical claim" and "the entailment claim." (In actual debate, of course, these claims usually are not clearly distinguished.)

The historical claim asserts that founding era Americans believed that the use of tax money for religious purposes was a violation of conscience. They may have been right or they may have been wrong, but this was what they believed; and their belief was constitutionalized in the First Amendment. Or at least so runs the claim. The entailment claim, by contrast, asserts that whatever Americans may have believed, or whatever they may believe today, the use of tax money for religious purposes just is a violation of conscience. So if our Constitution protects freedom of conscience, a principle of "no aid" to religion logically follows.

Interesting questions might arise if we were to conclude that the historical claim is correct but the entailment claim is not. What would follow, in other words, if we concluded that the founding generation believed that the use of tax money for religious purposes violated conscience but that their belief was (and is) mistaken? Should we conclude that the founding generation's belief, however misguided, was cemented into the Constitution, so that short of constitutional amendment we are bound by that belief despite its deficiencies? Or should we instead conclude

34. Feldman, supra note 33 , at $418-25$. 
that the case is comparable to that of the Fourteenth Amendment and the principle of racial equality? In discussions of Brown v. Board of Education, for example, it has become a sort of commonplace that the Framers believed they could constitutionalize equality without dismantling racial segregation in schools and other contexts, but we now realize that they were mistaken about the implications of their principle, and we are bound to respect what the principle really means, not what its enactors mistakenly thought it meant. ${ }^{35}$ Perhaps the ostensible link between freedom of conscience and "no aid" nonestablishment is like that?

We can avoid this conundrum, however, either by rejecting the historical claim or by accepting the entailment claim. And indeed, the historical claim seems hard to square with the historical evidence, because in fact the founding generation does not seem to have shared the view that the use of tax money for religious purposes was a violation of anyone's freedom of conscience.

Some Americans thought this, of course-probably quite a few. Jefferson is a good example. The famous preamble to his Virginia Bill for Religious Freedom did not use the term "conscience," but the idea is clearly there: the Bill's eloquent premise is that "Almighty God hath created the mind free," and the preamble reasons on to the proposition that "to compel a man to furnish contributions of money for the propagation of opinions which he disbelieves, is sinful and tyrannical." ${ }^{36}$ We might call this the Jeffersonian proposition. It is nicely congruent with the position advocated by Souter, Feldman, and others of a similar inclination. $^{37}$

It is clear, however, that other Americans of the founding generation rejected the Jeffersonian proposition. The fact that New Englanders continued for decades to maintain and defend state support for religion even as they also endorsed freedom of conscience is powerful evidence that they did not acknowledge the controversial entailment. ${ }^{38}$ For them (as for contemporary

35. See, e.g., ROBERT H. BORK, THE TEMPTING OF AMERICA 74-83 (1990).

36. The bill is reproduced in THE SUPREME COURT ON CHURCH AND STATE 25-27 (Robert S. Alley ed., 1988).

37. For example, in arguing for a strict "no aid" position in Everson v. Board of Education, Justicc Rutledge's dissenting opinion repeatedly quoted Jefferson's proposition. 330 U.S. 1 , at $28,44,46,60$ (1947) (Rutledge, J., dissenting).

38. Feldman, supra note 33 , at 416 . Feldman sometimes suggests that even those who lavored state financial support for religion acknowledged, at least in principle, that freedom of conscience required permitling objectors to opt out or to designate a recipi- 
human rights law), freedom of conscience and nonestablishment were independent propositions, and one could accept one proposition without accepting the other.

So the historical claim that Americans largely converged in believing that public monetary support for religion violates the consciences of taxpayers turns out to unpersuasive separationist wishful thinking, perhaps. But what about the entailment claim? It could be that Jefferson was right (even though not all Americans were, or are, willing to concede this). Maybe a taxpayer's freedom of conscience is violated when her tax dollars are spent on causes to which she is opposed in conscience. We need to consider the question more closely.

\section{OF COMPLICITY AND COERCED AFFIRMATIONS}

So, is there a good argument that using tax money to further ends to which a taxpayer is conscientiously (and not merely politically or prudentially) opposed violates the taxpayer's conscience? The question brings us back to $\mathrm{Al}$ and Betty. And as we saw earlier, at least in the abstract the proposition seems plausible. Wasn't this exactly the position taken by Henry David Thoreau, who refused to pay a tax to support the war with Mexico because he thought the war was morally unjustified? No one was asking Thoreau himself to pick up his rifle and join the troops, but Thoreau thought that paying a tax to support the war would implicate him in the moral offense $\mathrm{e}^{39}$-and he thereby became one of our legendary conscientious objectors.

Thoreau's view has its logic. Under the label of "complicity" or "cooperation with evil," we often regard people who support immoral activities as sharing in the immorality. People who fund terrorists are themselves complicit in the terrorism. People who give money to subversive or traitorous groups and activities are themselves guilty of subversion or treason. If it would be a violation of your conscience to do $\mathrm{X}$, it should similarly be a violation of conscience if you pay other people to do X.

ent of their choice for their own financial contribution. FELDMAN, supra note 10, at 41. And typically some such designation was allowed. But again, views differed: the argument that compelling a person to pay taxes to support a religion with which he disagreed violated freedom of conscience was considered at length and explicitly rejected in Barnes v. First Parish of Falmouth, 6 Mass. 401, 408-11 (1810), which objected that the claim "seems to mistake a man's conscience for his money." Id. at 408.

39. See Henry David Thoreau, On the Duty of Civil Disobedience (1849). 
So the logic is not implausible. Still, doubts arise. In assessing moral culpability, ethicists often see a crucial distinction between acting voluntarily with the intention of bringing about an evil and acting with the knowledge that bad consequences may be an unwanted side effect, but without the intention to produce those effects. ${ }^{40}$ In this vein, we might pronounce a judgment of complicity on someone who voluntarily contributes money to an immoral cause with the intention of bringing about an immoral result. But it is much less clear (Thoreau notwithstanding) that a person who is compelled by law and against his will to pay taxes that are used for immoral purposes should be held responsible for the evil. In addition, the person adjudged to be complicit will typically have contributed money consciously and specifically to some immoral cause or activity. The taxpayer, by contrast, pays money into a general fund which is used to support a whole variety of activities and programs-most of which the taxpayer knows little or nothing about, and many of which are presumptively beneficial. So again, it is far from clear that the taxpayer has any responsibility for the fact that some of the money is used for purposes to which she is conscientiously opposed.

Even more fundamentally, the complicity rationale as described thus far seems too sweeping, or too crude. The rationale does nothing to distinguish between $\mathrm{Al}$ and Betty, or between conscientious objections to religious and nonreligious expenditures. But as we have noted already, an argument that would operate to excuse from tax obligations everyone who is opposed in conscience to some use of public money could not be accepted, because accepting it would wreak havoc on the civil order.

So it seems we need a rationale that is narrower in the scope of protection it would afford. The statement from Jefferson quoted above suggests a possibility. What was "sinful and tyrannical," in Jefferson's statement, was not compelling a taxpayer to pay for ends of which he disapproved, but rather compelling him

40. See, e.g., Thomas Nagel, The Limits of Objectivity, in 1 THE TANNER LECTURES on Human Values 75, 130 (Sterling M. McMurrin ed., 1980):

It is also possible to foresee that one's actions will cause or fail to prevent a harm that one does not intend to bring about or permit. In that case it is not, in the relevant sense, something one does, and does not come under a deontological constraint, though it may still be objectionable for impersonal reasons.

See also John H. Garvey \& Amy V. Concy, Catholic Judges in Capital Cases, 81 MARQ. L. REV. 303, 318-19 (1998) (distinguishing between "formal cooperation" with evil, which is "always immoral," and "material cooperation," which "involves an act that has the effect of helping a wrongdoer, where the cooperator does not share in the wrongdoer's immoral intention") 
to support "opinions which he disbelieves." The statement suggests that claims of conscience have special force in matters of expression of opinion or belief. It is not necessarily tyrannical, or a violation of conscience, to make a taxpayer pay for programs (a war, for example) to which he is conscientiously opposed. But it $i$ tyrannical to force the taxpayer to subsidize the promulgation of opinions he disbelieves.

Carelessly considered, modern First Amendment decisions may appear to provide the material to support this argument. We might elaborate the argument in the form of two propositions, each of which can claim some support in the modern caselaw. First, the First Amendment protects citizens against compelled affirmations. Government cannot force people, in other words, to say things they do not believe. ${ }^{41}$ Second, for constitutional purposes, money talks. Contributing money to support the expression of an opinion is itself a way of expressing the opinion. ${ }^{42}$ From the conjunction of these propositions, it may seem to follow that government cannot force a person to contribute money that will be used to support the expression of opinions the person disbelieves and opposes: to do so would be to compel an affirmation, which is something the First Amendment forbids.

And this seems to be pretty much what Jefferson asserted. Modern caselaw does not in fact draw this conclusion, ${ }^{43}$ however; nor could it. Once again, the rationale is simply too broad to be acceptable. To put the point differently, even the narrower "compelled affirmation" rationale covers Betty as well as Al. Indeed, the logic of the rationale may fit Betty better than it fits Al. That is because Betty actually believes that the ideas that she wishes not to subsidize-evolution, perhaps, or "safe sex" for teenagers, or any number of other ideas regularly taught in the public schools - are false and pernicious. She would rather that they not be taught anywhere; and she certainly has scruples against supporting their inculcation in any context. Al, on the other hand, very likely does not think the same of the religious ideas that he wishes not to subsidize. Al might think this, of

41. The classic case is West Virginia State Board of Education v. Barnette, 319 U.S. 624 (1943). For a provocative discussion criticizing this venerable assumption, see Larry Alexander, Compelled Speech, 23 CONST. COMMENT. 147(2006)

42. See, e.g., Buckley v. Valeo, 424 U.S. 1 (1976).

43. See, e.g., Board of Regents v. Southworth, 529 U.S. 217 (2000). In a few instances, however, the Court has ruled in favor of persons who objected to being compelled to subsidize speech by private associations. See, e.g., Abood v. Detroit Bd. of Educ., 431 U.S. 209 (1977). The limited scope of this right is emphasized in Johanns v. Livestock Mktg Ass'n, 544 U.S. 550 (2005). 
course: he might be a devout atheist who would like to see religion disappear altogether. But in the America of 1790 or the America of 2006, it is at least as likely that Al's objection is not so much to the religious ideas themselves as to public support for the promotion of those ideas. Al typically will protest that he is not opposed to religion, and that he is perfectly content to have such religious beliefs taught in private homes and churches. Indeed, we could easily recast $\mathrm{Al}$ as a religious liberal who actually agrees with the religious ideas in question (whatever they happen to be), who in fact teaches similar ideas in his role as a Sunday School teacher, but who thinks the government should not be supporting and promoting such ideas. Hence, if Betty is not excused from paying her taxes she can fairly say that she has been "compel[led] ... to furnish contributions of money for the propagation of opinions which [s] he disbelieves"; $\mathrm{Al}$ may not be able to say as much.

But our question was whether a plausible argument could be advanced for recognizing Al's objection in conscience to subsidizing the teaching of religious ideas while refusing to recognize Betty's objection in conscience to subsidizing the promulgation of what she regards as anti-religious ideas. And it seems that the Jeffersonian contention fails to give us that argument. Its terms and its logic cover all publicly subsidized "propagation of opinions" that some taxpayers may "disbelieve"-religious or not. And given the fact that there are large numbers of citizens who "disbelieve" all manner of opinions taught in the public schools or subsidized in other ways, this broader argument is again one which, as a practical matter, we cannot expect courts ever to embrace.

So does it follow that the noble sentiments expressed in Jefferson's revered statute were simply misguided? Maybe. But perhaps we could rescue Jefferson by supposing that he wrote in a context in which subsidization of Christian ministers was thought to be just about the only form of public financial support for the expression of controversial opinions. If we view the matter in this way, then we might conclude that although Jefferson's view was viable and attractive on his assumptions and for his time and place, it simply cannot be embraced today in a world in which government pervasively makes and supports expressions of controversial opinions.

Either way, there is no apparent excuse for the opportunistic practice by which people like Justice Souter invoke the Jeffersonian proposition selectively to shut down aid for the sup- 
port of some controversial views while blithely failing to notice that similar subsidies are routinely made available for the support of a whole array of other controversial views. ${ }^{44}$

\section{ANTI-RELIGIOUS DISCRIMINATION?}

Our assessment of the entailment claim-or, rather, of its implausibility-may shed some light on the recurring controversy in which some citizens and Justices accuse other citizens and Justices of being "hostile" to religion, and in which the accused indignantly deny the charge.$^{45}$ We can charitably suppose that in ruling to invalidate various forms of aid to religion, separationist Justices are not being consciously hostile to religion. They are simply enforcing a constitutional prohibition as they understand it. Still, if a principle is consistently enforced against one set of causes and parties but conveniently forgotten when other causes and other parties' interests are at issue, suspicions will naturally arise. ${ }^{46}$

Suppose there is a classroom with a rule against talking in class without permission. The teacher disciplines Susy and Jane several times for whispering in class, and when they suggest that

44. So, should we conclude that the American commitment to nonestablishment is based on a mistake, and that the position of international human rights law requiring freedom of religion and freedom of conscience but not nonestablishment is the sounder position? See supra note 18 . Not necessarily. The ostensible connection of conscience to nonestablishment is a theme that has been historically important in this country, but it is surely not the only reason for favoring a constitutional prohibition on the establishment of religion. Those other reasons may be more than sufficient to support the American commitment. In addition, whether or not it was founded on conceptual errors or on conditions that no longer obtain, the commitment to "separation of church and state" is by now a firmly entrenched feature of the American constitutional tradition, arguably central to our national identity. Tradition itself furnishes a more than adequate justification for maintaining that commitment. See Steven D. Smith, Separation as a Tradition, $18 \mathrm{~J}$ LAW \& POLITICS 215 (2002).

To be sure, abandonment of the "entailment claim" might make for a somewhat differently shaped nonestablishment commitment. I have already noted, for example, how the specialized doctrine of taxpayer standing for establishment clause cases arguably rests on the implicit assumption that public expenditures for religious purposes violate the consciences of objecting taxpayers, and thereby cause the sort of personalized injury that allows them to bring suit. Without that assumption, the doctrine of standing might be different; a different standing doctrine might lead to different cases, and hence a different substantive doctrine on the subject. There is no way to know. But in any case, the basic commitment to nonestablishment does not scem threatened.

45. See, e.g., Santa Fe Indep. Sch. Dist. v. Doc, 530 U.S. 290, 318 (2000) (Rehnquist, J., dissenting) (arguing that the majority opinion "bristles with hostility to all things religious in public life").

46. Cf. Douglas Laycock, Formal, Substantive, and Disaggregated Neutrality toward Religion, 39 DEPAUl L. REV 993, 1010 (1990) (arguing that Justice Stevens' unusual voting pattern in religion cases can best be explained by "hostility to religion"). 
she is being mean to them she explains that, no, she is simply enforcing the rule. Rules are rules. But when Carlos and Horace engage in what looks like similar behavior, the teacher appears not to notice. If someone asks about this, she says she assumed that they were "conferring" or doing some other legitimate task. The teacher might actually believe her own explanations. But observers will understandably begin to suspect that her real (though perhaps subconscious) motives must be different than her announced ones.

By the same token, when people like Justice Souter routinely invoke the sanctity of conscience in supporting the claims of the Als of the world (even when the Als' claims have a tenuous grounding in the constitutional text) but seem not even to conceive of the possibility of employing the same reasoning in behalf of the Bettys of the world (even though the Bettys' claims have if anything a firmer footing in the text), observers are naturally going to wonder what is really going on. 